$\left.\begin{array}{c}\text { Sournals } \\ \text { INTERNATIONAL JOURNAL OF } \\ \text { ORGANIZATIONAL LEADERSHIP }\end{array}\right) \begin{gathered}\text { INDUSTRIAL } \\ \text { MANAGEMENT } \\ \text { INSTITUTE }\end{gathered}$

\title{
Successful takeovers and internal organizational variables: Experience from Croatia
}

\author{
Davor Filipović $^{1 *}$, Najla Podrug ${ }^{2}$, Tomislav Kandžija ${ }^{3}$ \\ ${ }^{1}$ Faculty of Economics and Business, University of Zagreb, J. F. Kennedy 6, 10000 Zagreb, Croatia \\ ${ }^{2}$ Faculty of Economics and Business, University of Zagreb, J. F. Kennedy 6, 10000 Zagreb, Croatia \\ ${ }^{3}$ Primorsko-Gorski Kotar County, Sloginkula 2/VI, 51000 Rijeka, Croatia
}

\begin{tabular}{|c|c|}
\hline & ABSTRACT \\
\hline \multicolumn{2}{|l|}{ Keywords: } \\
\hline $\begin{array}{l}\text { Mergers and } \\
\text { Acquisitions, Strategy, } \\
\text { Organizational Structure, } \\
\text { Corporate Culture, } \\
\text { Takeover Success }\end{array}$ & $\begin{array}{l}\text { Optimal acquisition strategy represents challenge for business world and academia. } \\
\text { Academia tries to identify all factors and perspectives influencing success of acquisition } \\
\text { strategy. The business reality is that most of M\&As do not accomplish prearranged } \\
\text { synergies and effects; therefore, the objective of this paper was to analyze the impact of key } \\
\text { organizational variables on the success of acquisition strategy. The aim of this paper was to }\end{array}$ \\
\hline $\begin{array}{l}\text { Received } \\
\text { 01 September } 2016\end{array}$ & $\begin{array}{l}\text { determine the impact of strategy, organizational structure, and corporate culture in the } \\
\text { change process in target company. To this end, success of target company is defined by }\end{array}$ \\
\hline $\begin{array}{l}\text { Received in revised form } \\
05 \text { January } 2017\end{array}$ & $\begin{array}{l}\text { comparison of business performance prior and after the acquisition process by using } \\
\text { financial indicators. Empirical research was conducted on the sample of target companies }\end{array}$ \\
\hline $\begin{array}{l}\text { Accepted } \\
\text { 31 January } 2017\end{array}$ & $\begin{array}{l}\text { in Republic of Croatia in the period from } 1998 \text { until } 2006 \text {. Data was collected via } \\
\text { questionnaire followed with business performance analysis for the period of three years } \\
\text { after the transaction's execution. Empirical research has confirmed a statistically significant }\end{array}$ \\
\hline $\begin{array}{l}\text { Correspondence: } \\
\text { dfilipovic@efzg.hr }\end{array}$ & $\begin{array}{l}\text { correlation between the radical change in the target's strategy and its performance after the } \\
\text { takeover. Likewise, research confirmed statistically significant correlation between changes } \\
\text { in organizational structure and target's performance after the takeover and statistically } \\
\text { significant correlation between larger change in corporate culture and target's performance } \\
\text { after the takeover. Scientific contribution of this paper was the verification of importance of } \\
\text { changes in strategy, organizational structure, and corporate culture for successful change } \\
\text { management in target companies. }\end{array}$ \\
\hline
\end{tabular}

(C)AIMI Journals

Since the end of $19^{\text {th }}$ century, mergers and acquisitions, as a part of the growth strategy, but also as a research field of different scientists and consultants show important and great phenomenon of advanced capitalist world (Kandžija, Filipović, \& Kandžija, 2014). 
Advancement of the company through M\&As present the opportunity to approach to new markets and resources, and success or failure of M\&As is of considerable significance not only for companies included that in that procedure, but also for all participants of that procedure and for the whole economy (Filipović, Sapunar, \& Sapunar, 2011). In the contemporary literature, it is difficult to find a book, a paper or other scientific work in the field of mergers and acquisitions which has not addressed issues such as the impact of mergers and acquisitions on shareholder's wealth, motives for mergers and acquisitions, the realization of planned synergies, increase of operational efficiency in the acquired companies, reasons why mergers and acquisitions have not achieved the expected benefits and, finally, the social impact of mergers and acquisitions.

Success of mergers and acquisitions can be observed from various perspectives. Presenting the fact that mergers and acquisitions influence great number of stakeholders and having in mind the fact that interests of these groups follow a different direction, perceived transactions can at the same time affect positively on one group and negatively on other group of stakeholders. Financial theory mostly concentrates on shareholder's wealth as a criterion for the prosperity and triumph of mergers and acquisitions, regarding the fact that shareholders are the residual owners of the company (Kandžija et al., 2014), while many studies focused on analysis of the performance of companies involved in M\&A activities. The most common way of conducting an analysis of companies' performance is a comparison of corporate performance before and after the takeover by using different financial indicators (Tirole, 2006).

Since homogenous opinion on M\&A success in academic community has not yet been reached, and taking into consideration that the success of these transactions is affected by many organizational variables, the main objective of this research is the analysis of the impact of changes in strategy, structure, and culture, as key internal organizational variables on takeover success of Croatian companies in the period from 1998 to 2006. Successful takeover is explained as takeover in which aimed company acts in a pleasing way after the takeover than in the period before the takeover (Filipović, 2012). Therefore, the target's performance will be analyzed in the period of three years before and three years after the takeover using questionnaire and financial data. In addition to the results of the empirical research, the scientific contribution of this paper will be visible through the synthesis and literature review in the field of mergers and acquisitions. Such analysis will provide new scientific insights that will also be applicable in business practice.

\section{Strategy as a Determinant of Takeover Success}

Strategy, as an internal organizational variable, determines not only the takeover success, but also the performance of the overall company. The success of the target company after the takeover can be viewed as a combination of a successfully formulated and implemented strategy which leads to an increase of excellence in all business phases. The essence of the implementation process is a strategic change. Implementation of the strategy is nothing more than replacing the old strategy with a new one which should make the company more successful compared to its competitors (Cingula, 2005). Etymologically observed, the word strategy comes from the Greek word strategos which means army in general and is derived from the term stratos which means the army, and the word agein which describes the verb to 
lead. Therefore, strategy can be seen as the art of leading the army. Although originally created as a military concept, strategy has found its place in the business world after the 1960s, at the initiative of Barnard and Sloan who emphasized the need for a strategy within the business context (Buble, 2005). According to Gamble and Thompson (2012), strategy consists of competitive moves and approaches that managers use to attract customers and satisfy their needs, as well as to successfully compete, increase revenue, and achieve the defined objectives. Porter (1980) describes the strategy as taking offensive or defensive actions to create a defensive position in the industry and help the company successfully fight with competitive forces and ultimately achieve superior returns on invested capital. Tipurić (1999) points out that strategy has to create the conditions for the long term survival of the company and achieving better results than the competition is the essence of successful strategy.

Companies switch from one strategy to another through M\&As. Choices on strategy can be explained only by understanding the resources on which companies compete and how these resources erode by time. Therefore, through M\&As companies renew themselves by acquiring new resources which enable them to compete and create competitive advantage (Sudarsanam, 2010). A company can create a successful strategy independently of the environmental characteristics by relying on the valuable and rare resources that it possesses. Such approach to strategy development is based on the resource theory that emphasizes how the internal capabilities of companies are crucial for successful performance. The basic premise of the resource-based theory is that firms differ because each of them has a unique set of resources. Given the fact that some of these resources cannot be instantly accumulated, the choice of the company's strategy is limited by available resources and the speed at which the company can buy or develop new resources (Collis \& Montgomery, 2005). Ramaswamy (1997) examined horizontal mergers and acquisitions in the U.S. banking industry. The results showed that mergers and acquisitions of banks with similar strategic characteristics were more successful than those in which the banks had different strategies. The concept of strategic similarity is based on the mode of resource allocation that indicates which strategy company will implement. In a situation where two companies allocate resources in a similar way, measured through strategically relevant characteristics, it can be concluded that the companies have similar strategies. When determining strategically relevant characteristics, Ramaswamy analyzed market share, marketing expenditures, risk aversion by managers, the proportion of fixed costs in the revenues, and the client structure. On a sample of 262 mergers and acquisitions in the banking industry of the European Union in the period from 1992 to 2001, Altunbaşand Marqués (2008) has analyzed the impact of strategic similarities on company's performance after the transaction. The research was based on Ramaswamy's model and it was found that strategic similarities of the acquirer and the target have a positive impact on the company's performance after the takeover.

Allred, Boal, and Holstein (2005) describe mergers and acquisitions in terms of marriage and point out that similarity between spouses can result in harmonized relations in the future implying that similar strategies of the acquirer and the target company are essential for a successful company's performance after the takeover. Research by Kim and Finkelstein (2009) analyzed 2204 takeovers executed by U.S. commercial banks in the period from 1989 to 2001 and the results of the research suggest that similarities in strategies of companies involved in 
M\&A transaction are important for the companies' success after the transaction. In a research on a sample of 1100 companies which have participated in mergers and acquisitions in the period from 1970 to 1989, Harrison, Hitt, Hoskisson, and Ireland (1991) analyzed the correlation between strategic similarities and business performance after the transaction. In their research, the definition of strategic similarity includes a number of key strategic variables such as investment in research and development, administrative intensity, debt, and capital level. Although these variables are related to the realization of potential synergies, the results of their research showed that differences in these variables between acquirer and target have a positive impact on the target's performance after the transaction.

Mergers and acquisitions theories emphasize the importance of increasing company's efficiency as a result of the realization of potential synergies. Among others, one form of synergy can be achieved through replacement of incompetent management or trough management with complementary competences (Larsson \& Finkelstein, 1999). Taking into account the impact of the market for corporate control on target companies, it is assumed that the incompetent management will be replaced after the takeover and that a radical change of strategy in the target company will result in better performance of the target after the takeover. The goal of radical change in strategy or a strategic turnaround is establishing disrupted harmony between the company and its environment by changing the company's strategic position. A radical change in strategy is needed in situations where company lost its competitive advantage and when there is an obvious decrease in profitability as well as other financial and non-financial indicators compared to the competition (Tipurić, 2005). Some of the research regarding strategies of companies involved in M\&A transactions suggest that the differences in strategies between acquirer and target are more appropriate for increasing shareholder value and better for companies' performance after the transaction compared to a situation where acquirer and target have similar strategies (Barney, 1986). By changing the strategy in the acquired company the new management can allocate resources in a more efficient way which will result in a better business performance of acquired company after the transaction (Harrison et al., 1991).

\section{Impact of Organizational Structure on Takeover Success}

Some researchers attribute high percentage of unsuccessful takeovers to inadequate organizational structure of the target company after the takeover. In this research the impact of organizational structure on the takeover success is based on the premise that structure follows the strategy. Company's formal structure is, among other things, the result of the appropriate strategy (Sikavica \& Novak, 1999). A change of the organizational structure occurs after a radical change in the target's strategy after the takeover. Changes in the organizational structure will be greater in the case of merger because two or more companies will merge to form a completely new company, while changes when takeover occurs will be slightly smaller in scale (Sikavica \& Novak, 1999).

The purpose of the organizational structure can be seen through the division of labor between members of the organization and coordination of their activities directed towards the achievement of organizational goals. Structure defines tasks, responsibilities, roles, and relationships among employees, and communication channels (Mullins, 2010). Organizational 
structure is also seen as a tool used by managers to coordinate a number of functions, divisions, and business units to take advantage of their skills and competencies (Hill \& Jones, 2008). Drucker (1989) points out that a good organizational structure has an extremely important impact on the company's performance. Drucker also notes that a good structure itself does not affect a successful performance and stresses that bad organizational structure completely prevents company from successful performance regardless of the individual quality of the managers who run the company. Therefore, the improvement of the organizational structure can impact better performance of the company.

Timely changes in the organizational structure and the integration of employees after a merger or acquisition are highlighted as key factors for the success of mergers and acquisitions in a number of studies (DePamphilis, 2008). Changes in the organizational structure are motivated by the realization of operational synergies between the companies involved in a transaction. One of the ways through which operational synergies can be created is rationalization of operations which includes elimination of certain functions in the acquired company or creating new ones that will facilitate the implementation company's new strategy (Damodaran, 2002). The target company usually has certain products and systems that the acquirer does not want or that need to be changed in order to create value. Therefore, changes in the organizational structure of the target are necessary after the transaction. Value is created only if new organizational units are more efficient and effective. Given the fact that the target has different procedures and routines compared to the acquirer, the target should be reconfigured and assimilated with the procedures of the acquirer. Target companies often need extensive change in the organizational structure to get rid of redundant resources and to combine acquirer's resources in a manner that would result in better performance of the acquired or the newly created company (Karim, 2006). The most common organizational changes after the takeover is the rationalization of operations that reduce costs. Reducing fixed costs is usually achieved by laying off employees from support functions, eliminating inefficient departments, and selling inefficient assets (Agwin, 2007).

Research by Puranam, Singh, and Chaudhuri (2009) focused on the impact of the target's structural integration on the success of mergers and acquisitions. The authors point out that the degree of integration between the two companies depends on the correlation between strategic and organizational needs, as well as cultural factors that are a prerequisite for the transfer of capacity and value creation. In that research, structural integration is defined as a combination of originally distinct organizational units into a single organizational unit after the acquisition. The results suggest that the structural integration generates strong coordination effects between acquirers and target companies which are of particular importance in situations of significant interdependence between the companies.

Numerous research studies have shown that in addition to laying off employees from support functions, turnover of managers and key employees also increases after the merger or acquisition. Talented employees, especially those with skills that are hard to find in the labor market, often leave after the acquirer integrates the target company into its business system thus weakening the innovating ability of the newly formed entity (Ernst \& Vitt, 2000). Turnover of managers is an integral part of the M\&A process and occurs as a result of the elimination of positions that are redundant or overlapping. However, in order to perform well 
after the acquisition, it is extremely important to retain key employees, especially if the merger or acquisition occurred in the high tech industry (DePamphilis, 2014).

In situation of mergers of equals there are often managerial misinterpretations related to equality in decision-making. To prevent such misunderstandings between managers, Marks and Mirvis (2000) suggest the development of a transitional organizational structure during the transaction. Such temporary structure would be used for three to six months and would facilitate coordination and greatly assist in the implementation of the changes. The structure can be viewed as a container of organizational resources, and the combination of organizational units after the takeover implies the reconfiguration of resources within the organization. It can be said that companies adapt and experiment with the structure to align resources between the acquirer and the target company. Changes in the organizational structure of the target after the takeover are necessary despite the possible loss of key employees.

\section{Importance of the Corporate Culture for Takeover Success}

The importance of corporate culture is particularly evident in recent years since many corporations ended up on the front pages of the world media due to their misconduct and unethical behavior that has created suspicion and distrust of all stakeholders, along with a negative public image. Corporate or organizational culture is a general concept with many different meanings that are difficult to define or explain precisely. The concept of corporate culture has evolved from anthropology, sociology, and psychology, and became popular in early 1980s. Although people are often unaware of the corporate culture, it has a prevalent influence on their behavior. A widespread and an easy way of conceptualizing corporate culture is the concept according to which culture is seen as the way things are done in the corporation. Farmer (2005) postulates that corporate culture describes the behavior of employees while no one watches or controls them and it represents a collection of shared (expressed or implied) beliefs, values, rituals, stories, myths, and a special way of expressing, which all together cultivates a sense of community among all members of the corporation. According to Farmer corporate culture differentiates the "company winners" from the "company losers."

Peters and Waterman (2008) were among the first to highlight the impact of corporate culture on business performance. Peters and Waterman emphasize that every organization must have firm beliefs which will serve as starting point for all its policies and actions in order to survive and achieve success. According to these authors, as well as Heller (1997) and Goldsmith and Clutterbuck (1998), consistently following these beliefs is the most important factor in corporate success. Although there is no convincing empirical evidence about the correlation between corporate culture and business performance of the corporation (Safford, 1988), the generally accepted paradigm suggests that corporate culture is an important factor in every corporate success (Mullins, 2010). Relying on this paradigm, it can be concluded that the corporate culture is extremely important for the success of mergers and acquisitions.

By ignoring the corporate culture, often because it is made up of segments that are not visible, managers often tend to neglect the impact of culture on the M\&A success (Chatterjee, Lubatkin, Schweiger, \& Weber, 1992). For many managers, the primary reason for mergers and acquisitions is achieving the " $2+2=5$ " effect, i.e. the realization of potential synergies and 
improvement of the overall performance which will result in increasing the competitive advantage of companies that they manage (Appelbaum, Gandell, Yortis, Proper, \& Jobin, 2000). Despite the popularity of mergers and acquisitions, it has been investigated that, more than two-thirds of large merger deals neglect to generate value for shareholders (Cingula, Filipović, \& Podrug, 2010). Profitability of aimed companies, on average decreases after an acquisition (Ravenscraft \& Scherer, 1989). The rate of M\&A failure is from 55 to 70 percent (Lodorfos \& Boateng, 2006). Since synergies are infrequently percieved, M\&A literature demonstrates that there has been great interest in exploring the human and cultural features of M\&As (Filipović et al., 2011). The literature drawn on cultural differences is derived from the organizational behavior school of thought. Cultural differences are especially significant in the post-acquisition period (Quah \& Young, 2005). Systematic research implies that the most prominent danger for value creation comes after two companies try to merge operations (Filipović et al., 2011). Radical changes of corporate culture in companies that have been taken over, as well as the lack of culture assimilation between merging companies, are often referred to as the causes of unsuccessful mergers and acquisitions (Nahavandi \& Malekzadeh, 1988). Unharmonious organizational cultures are the most important reason of M\&A failure (Carwright \& Cooper, 1993). Cultural compatibility is not enoughfor M\&A success, but cultural heterogeneity definitely will not contribute to M\&A success (Brock, 2005; Jemison \& Sitkin, 1986).

If there are similarities in corporate cultures of the acquirer and the target, i.e., if there is a similarity in the way of conducting business as well as in decision-making and behavior of employees, the similarity reduces the possibility of conflict, which will reflect on greater likelihood of successful performance after the takeover (Bruton, Oviatt, \& White, 1994). Larsson and Lubatkin (2001) state that in order to have successful merger or acquisition, transactions in which corporate culture of the acquirer significantly differs from the target's culture should be avoided. In a situation where the corporate cultures significantly differ, the target's corporate culture changes after the takeover in accordance with the preferences of the acquirer (Chatterjee, 1986). Changing the corporate culture of the target after the takeover has dysfunctional consequences for the integration of the target in the business system of the acquirer. Nevertheless, after taking over the company, new management frequently changes the corporate culture to encourage employees to accept new values and ways of working in order to increase productivity. However, there are also research studies that found a negative correlation between the similarity of corporate culture and the performance of the target and the acquirer after the takeover (Chatterjee et al., 1992). Lodorfos and Boateng (2006) conducted a research in chemical industry in period from 1999 till 2004 and they had 32 interviews with senior managers who participated in 16 major M\&A deals. Findings of their research identified cultural differences as the key element in the M\&A success. Human resources tend to react negatively after being acquired (Filipovićet al., 2011). However, the strength duration and dysfunctional effects of such reaction vary between different M\&As (Filipović et al., 2011). The negative employee reaction is defined as cultural clash (Cartwright \& Cooper, 1993; Chatterjee et al., 1992). Cultural clash may affect the commitment, collaborationand turnover of acquired employees, (Krishanan, Hitt \& Park, 2007), acquirer's shareholder value, and performance of the acquired company (Chatterjee et al., 1992). Stahl 
and Voigt (2008) found that out of 24 research studies about the impact of corporate culture on the M\&A success, only 9 have a positive impact on shareholder's wealth, while 15 studies show that culture has no impact on business performance measured by accounting information. Taking into account the previously mentioned research, it is evident that corporate culture influences the positive or negative outcome of mergers or acquisitions. In a situation where a target is taken over due to poor performance, it is necessary to change target's corporate culture so that target can get back at the right track i.e. perform better after the takeover.

\section{Research Hypotheses}

The following research hypotheses guided the study:

$\mathbf{H}_{1}$ : Radical change in business strategy after the takeover is related with better target's performance after the takeover.

$\mathbf{H}_{2}$ : Changes in organizational structure of the target company are related with better target's performance after the takeover.

$\mathbf{H}_{3}$ : Employees' perception about larger change of corporate culture after the takeover is related to better target's performance after the takeover.

\section{Method}

Four research approaches on success of mergers and acquisitions, namely event study approach, accounting approach, case study or clinical study, and a survey based approach can be derived from recent literature (Bruner, 2001). Research concerning the effect of mergers and acquisitions on shareholder wealth is largely based on short-term effects, and is built on the premise that the declaration of potential transactions present new information on the market upon which the investors' expectations are built and accordingly displayed in the stock price (Kandžija et al., 2014). The event study methodology is commonly used in this type of research. Event study methodology is based on the abnormal returns which are the result of discrepancy between the realized return and the expected return of company's industry in the event that transaction did not happen. That methodology came into use since 1969 when Fama, Fisher, Jensen, and Roll (1969) applied it to research considering the effects of stock splits on share prices. A large number of studies focused on the accounting aspects of the transactions where the business performance of the company is analyzed before and after mergers and acquisitions in order to determine how the performance has changed after the transactions (Kandžija et al., 2014). The most common way of analyzing business performance is through comparison of company's performance before and after the transaction by using accounting indicators such as sales, operating income, income/loss, cash flow, and profit margins (Marynova and Renneboog, 2008). Questionnaires and interviews also came into use as a key method of research of M\&A since they usually present answers to questions considering the profitability or other observed variables in the acquired companies and achieving anticipated synergies (Kandžija et al., 2014). The examinations of individual cases deliver detail study of one or few transactions which lead to conclusions about the acquisition success (Schoenberg, 2006). It is important to note that every method used in research on the M\&A success has both its advantages and disadvantages and surveying method was used within this research because 
of the character of observed variables which included strategy, organizational structure, and corporate culture.

Measuring instrument (questionnaire) for testing the hypotheses of this research is composed of a set of questions that the respondents including board members and company managers answered and indicated their agreement/disagreement with suggested statements whereat a Likert measurement scale of five degrees was used (Filipović, 2012). Propositions used in various measurement scales are either initially progressed for research purposes, or managed and adapted from existing measurement scales that can be found in the applicable scientific literature (Filipović, 2012). In the first part of the questionnaire general data about research participants (position within the company, gender, age, education, working experience), general data about the target (target's name, industry, size), and general data about the acquirer (domestic or international, legal entity or private person) were gathered. Second part of the measuring instrument encompassed of questions regarding the impact of internal organizational variables on takeover success in order to accept or reject proposed hypotheses.

Empirical research was conducted among Croatian companies, which have been taken over. Following this, 233 transactions in the time from 1998 till 2010 were set down in Bloomberg and Mergermarket databases. During this period, another 401 transactions was recorded with the comprehensive examination of the information library of the Croatian Agency for Supervision of Financial Services; therefore, they were combined with the transactions from Bloomberg and Mergermarket databases that comes to a total of 634 transactions. Regarding the fact that the current research examines transactions in non-financial sector, the sample on which the empirical research was conducted comprised of 598 companies. To investigate the effect of the market for corporate control on the act of companies that were taken over, it is crucial that at least three years have passed since takeover (Filipović, 2012).

A total of 43 completed questionnaires were obtained after the starting of primary research during sixty days, and returned questionnaires indicated a return rate of $7.19 \%$. Regarding the sensitivity of the examined phenomena and complexity of analysis, the rate of return of questionnaires was acceptable. The complexity of the analysis is revealed in the fact that the research contained only companies in which at last three years passed after the takeover. Extra criteria were concerned the fact that the respondent, namely the president or board member or senior manager should be incorporated in the acquisition procedure and familiar with the acquisition activities, and also working in the company that was obtained at least 5 years to recognize and evaluate the changes that have happened after acquisition. Out of the total number of received questionnaires, 30 companies that acted effectively after the takeover were distinguished (69.8\%) and 13 that performed worse after the transaction (30.2\%) (Kandžija et al., 2014). In the analysis of empirical data collected in this research, large number of statistical techniques was used. Overall data analysis was conducted using statistical software package SPSS 17.0.

\section{Results}

Empirical research begins by testing the hypotheses. To test the first hypothesis, research participants were asked about radical change in business strategy after their company was taken over. Questions regarding $\mathrm{H}_{1}$ referred to defining business strategy before the takeover and its 
subsequent change. Firstly, research participants were supposed to identify target's business strategy that was implemented before the takeover (cost leadership, differentiation, focus, combination of cost leadership and differentiation, unique resources hard to accumulate by competitors or vague politics, and plans for realization of target's goals). All strategies were described in detail to ensure the most precise answers. Afterwards, radical change of business strategy was explained to help research participants to answer the question whether there was radical change in business strategy after the takeover. Radical change in business strategy was defined as strategic turnaround aimed to establish disrupted harmony between the company and its environment by changing the company's strategic position in situations where target lost its competitive advantage, and when there is an obvious decrease in profitability as well as other financial and non-financial indicators compared to the competition. Last question regarding $\mathrm{H}_{1}$ referred to the opinion of research participants about the relatedness of radical change in business strategy on target's performance after the takeover. Their answers are presented in Table 1 as it shows the radical change of strategy and target's performance after the takeover.

Table 1

Radical Change of Strategy and Target's Performance after the Takeover

\begin{tabular}{lcccc}
\hline \multirow{2}{*}{ Change of Target's Business Strategy after the Takeover } & \multicolumn{2}{c}{ Performance After the Takeover } & \multirow{2}{*}{ Total } \\
\cline { 3 - 4 } & Number of Companies & Worse & \multicolumn{2}{c}{ Better } \\
\multirow{2}{*}{ Yes } & $\%$ & 5 & 25 & 30 \\
& Number of Companies & $16.7 \%$ & $83.3 \%$ & $100.0 \%$ \\
No & $\%$ & 4 & 5 & 9 \\
& Number of Companies & $16.7 \%$ & $55.6 \%$ & $100.0 \%$ \\
Total & $\%$ & 9 & 30 & 39 \\
& & $23.1 \%$ & $76.9 \%$ & $100.0 \%$ \\
\hline
\end{tabular}

Source: Authors' Research

Out of the total number of survey participants who answered the question about the change in strategy after the takeover, it is evident that 30 companies radically changed their strategy, whereas in 9 transactions strategy remained unchanged. Out of the total number of companies which radically changed their strategy after the takeover, 25 or $83.3 \%$ of them performed better, while 5 companies or $16.7 \%$ performed worse compared to the period prior to the takeover. Out of 9 companies in which there was no change in strategy, $55.6 \%$ of them performed better and $44.4 \%$ performed worse in the period after the transaction. To determine the statistical correlation between the radical change in business strategy of the target and its performance after the takeover, a Chi-square test with the symmetric measures was used.

Table 2 represents the chi-square test for $\mathrm{H}_{1}$.

Table 2

Chi-Square Test for $H_{1}$

\begin{tabular}{lccccc}
\hline Chi-Square Test & Value & df & Asymp. Sig. (2-Sided) & Exact Sig. (2-Sided) & Exact Sig. (1-Sided) \\
\hline Pearson Chi-Square & $3.009^{\mathrm{a}}$ & 1 & 0.083 & 0.170 & 0.103 \\
Continuity Correction $^{\mathrm{b}}$ & 1.648 & 1 & 0.199 & & 0.103 \\
Likelihood Ratio & 2.737 & 1 & 0.098 & 0.170 & 0.103 \\
Fisher's Exact Test & & & & 0.170 & \\
\hline
\end{tabular}

Source: Authors' research

Table 3 indicates the symmetric measures of chi-square test for $\mathrm{H}_{1}$. 
Results of the chi-square test showed a statistically significant correlation $(\mathrm{p}=0.083)$, at the significance level lower than $10 \%$ between the radical change of business strategy and target's performance after the takeover. Besides a statistically significant correlation, a practical correlation is also evident because $83.3 \%$ of the companies in which strategy was radically changed performed better after the takeover, while out of all the companies that did not radically changed the strategy, $55.6 \%$ of them were more successful after the takeover.

Table 3

Symmetric Measures of Chi-Square Test for $H_{1}$

\begin{tabular}{lccc}
\hline Symmetric Measures & Value & Approx. Sig. & Exact Sig. \\
\hline Phi & -0.278 & 0.083 & 0.170 \\
Cramer's V & 0.278 & 0.083 & 0.170 \\
Contingency Coefficient & 0.268 & 0.083 & 0.170 \\
\hline
\end{tabular}

Source: Authors' research

By taking advantage of the variance analysis (Table 4), it has also been confirmed that there is a significant difference $(p<0.001)$ between mean scores of research participants coming from the companies that performed worse (they think that the impact of radical change in business strategy on target's company performance is week - mean score 1.31) and better (they think that the impact of radical change in business strategy on target's performance is very strong - mean score 3.69) performance after the takeover.

Table 4

Variance Analysis for $H_{1}$

\begin{tabular}{lccccc}
\hline ANOVA & Sum of Squares & df & Mean Square & F & Sig. \\
\hline Between Groups & 50.929 & 1 & 50.929 & 55.094 & 0.000 \\
Within Groups & 36.976 & 28 & 0.924 & & \\
Total & 87.905 & 29 & & & \\
\hline
\end{tabular}

Source: Authors' research

Based on the variance analysis and since chi-square test confirmed a statistically significant correlation between the change in business strategy and target's performance after the takeover, and given the fact that there is a practical correlation, it can be concluded that a radical change in strategy after the takeover is related with better performance of the target company which confirms $\mathrm{H}_{1}$.

In order to test $\mathrm{H}_{2}$, research participants answered four questions. First question was general and directed to find out whether there was a change in organizational structure. If there was a change in organizational structure, research participants were asked about the type of change defined as elimination of certain functions or departments, merging existing functions or departments and/or selling of organizational units. Third question referred to departments in the target where changes mostly occurred (accounting, finance, marketing, human resources, procurement, sales, research and development or elsewhere). Furthermore, participants in the fourth question needed to indicate their opinion whether changes in organizational structure were associated with improved performance after the takeover. Table 5 shows the descriptive statistics regarding changes in organizational structure and target's performance after the transaction. 
Table 5

Changes in Organizational Structure and Target's Performance after the Takeover

\begin{tabular}{|c|c|c|c|c|}
\hline \multirow{2}{*}{\multicolumn{2}{|c|}{ Change of Organizational Structure }} & \multicolumn{2}{|c|}{ Performance After the Takeover } & \multirow[t]{2}{*}{ Total } \\
\hline & & Worse & Better & \\
\hline \multirow{2}{*}{ Yes } & Number of Companies & 4 & 27 & 31 \\
\hline & $\%$ & $12.9 \%$ & $87.1 \%$ & $100.0 \%$ \\
\hline \multirow{2}{*}{ No } & Number of Companies & 9 & 3 & 12 \\
\hline & $\%$ & $16.7 \%$ & $25.0 \%$ & $100.0 \%$ \\
\hline \multirow{2}{*}{ Total } & Number of Companies & 13 & 30 & 43 \\
\hline & $\%$ & $30.2 \%$ & $69.8 \%$ & $100.0 \%$ \\
\hline
\end{tabular}

Source: Authors' research

Of the total number of analyzed companies, 31 of them have experienced changes in the organizational structure, while structure remained unchanged in 12 companies. Results of descriptive statistics indicated that out of the total number of companies which had changes in organizational structure, 27 or $87.1 \%$ of them performed better, while only 4 companies or $12.9 \%$ performed worse. Out of the 12 companies in which there was no change in strategy, 3 companies performed better while 9 performed worse in the period after the transaction. The correlation between changes in organizational structure of the target and its performance after the takeover was determined by Chi-square test with the symmetric measures. Table 6 presents the chi-square test for $\mathrm{H}_{2}$.

Table 6

Chi-Square Test for $\mathrm{H}_{2}$

\begin{tabular}{lccccc}
\hline Chi-Square Test & Value & df & Asymp. Sig. (2-Sided) & Exact Sig. (2-Sided) & Exact Sig. (1-Sided) \\
\hline Pearson Chi-Square & $15.816^{\mathrm{a}}$ & 1 & 0.000 & 0.000 & 0.000 \\
Continuity Correction $^{\mathrm{b}}$ & 13.009 & 1 & 0.000 & & 0.000 \\
Likelihood Ratio $^{\text {Fisher's Exact Test }}$ & 15.365 & 1 & 0.000 & 0.000 & 0.000 \\
\hline
\end{tabular}

Source: Authors' research

Table 7 indicates the symmetric measures of the chi-square test for the $\mathrm{H}_{2}$.

Table 7

Symmetric Measures of the Chi-Square Test for $\mathrm{H}_{2}$.

\begin{tabular}{lccc}
\hline Symmetric Measures & Value & Approx. Sig. & Exact Sig. \\
\hline Phi & -0.606 & 0.000 & 0.000 \\
Cramer's V & 0.606 & 0.000 & 0.000 \\
Contingency Coefficient & 0.519 & 0.000 & 0.000 \\
\hline
\end{tabular}

Source: Authors' research

Results of the Chi-square test and its symmetric measures for $\mathrm{H}_{2}$ (Table 6 and 7) showed that there was significant correlation $(p<0,001)$ between changes in organizational structure and target's performance after the takeover. Out of the total number of target companies which changed organizational structure, $87.1 \%$ of them had better performance after the takeover and only $25 \%$ of the target companies which did not change the organizational structure had better performance.

Using variance analysis (Table 8) it has been confirmed that there was significant difference between mean scores of research participants $(\mathrm{p}=0.038)$ regarding changes in organizational 
structure. Research participants who came from the target companies with worse performance after the takeover (12.9\% of total participants - mean score 3.00 ) believed that there was a moderate correlation between changes in organizational structure and company performance and $87.1 \%$ of them (coming from the companies with better performance - mean score 3.61) stated that there was moderate impact of changes in organizational structure on target's performance. Table 8 shows the variance analysis for $\mathrm{H}_{2}$.

Table 8

Variance Analysis for $\mathrm{H}_{2}$

\begin{tabular}{lccccc}
\hline ANOVA & Sum of Squares & df & Mean Square & F & Sig. \\
\hline Between Groups & 2.294 & 1 & 2.294 & 4.679 & 0.038 \\
Within Groups & 16.679 & 29 & 0.491 & & \\
Total & 18.972 & 30 & & & \\
\hline
\end{tabular}

Source: Authors' research

Since chi-square test confirmed a statistically significant correlation $(\mathrm{p}<0.001)$ between changes in organizational structure and target's performance after the takeover and based on the variance analysis, it can be concluded that changes in organizational structure of the target company are related with better target's performance after the takeover which confirms $\mathrm{H}_{2}$.

In order to accept or reject $\mathrm{H}_{3}$, participants were asked about change in corporate culture after their company was taken over. Firstly, the concept of corporate culture was defined and afterwards, research participants were supposed to identify whether acquirer imposed its own corporate culture to the target, whether corporate cultures of acquirer and target were integrated and whether corporate culture of the target stayed the same. Besides, research participants graded the degree of change in corporate culture and expressed their opinions about the impact of corporate culture on the target's performance after the takeover. Answers of the research participants are presented in Table 9 which shows the corporate culture and target's performance after the takeover.

Table 9

Corporate Culture and Target's Performance after the Takeover

\begin{tabular}{|c|c|c|c|c|}
\hline \multirow{2}{*}{\multicolumn{2}{|c|}{ Corporate Culture After the Takeover }} & \multicolumn{2}{|c|}{ Performance After the Takeover } & \multirow[t]{2}{*}{ Total } \\
\hline & & Worse & Better & \\
\hline Acquirer Impose its & Number of Companies & 0 & 16 & 16 \\
\hline Corporate Culture & $\%$ & $0 \%$ & $100.0 \%$ & $100.0 \%$ \\
\hline Corporate Culture was & Number of Companies & 0 & 11 & 11 \\
\hline Integrated & $\%$ & $0 \%$ & $100.0 \%$ & $100.0 \%$ \\
\hline No Change in Corporate & Number of Companies & 13 & 3 & 16 \\
\hline Culture & $\%$ & 86.7 & $18.8 \%$ & \\
\hline \multirow[t]{2}{*}{ Total } & Number of Companies & 13 & 30 & 43 \\
\hline & $\%$ & $31.0 \%$ & $69.0 \%$ & $100.0 \%$ \\
\hline
\end{tabular}

Source: Authors' research

Out of the total number of the analyzed companies, in 16 of them the acquirer imposed its corporate culture, while in 11 transactions corporate cultures of the acquirer and the target were integrated. In 9 companies there was no change in corporate culture after the takeover. In analyzing all targets that there was a change in corporate culture, it is obvious that all of them performed better after the takeover. Out of the 16 targets in which there was no change in corporate culture after the takeover, $86.7 \%$ of them performed worse after the takeover while 
only $18.8 \%$ of them performed better. In order to determine correlation between changes in target's corporate culture and its performance after the takeover, a Chi-square test with the symmetric measures was used.

Table 10 clearly indicates the chi-square test for $\mathrm{H}_{3}$ and Table 11 presents the symmetric measures of the chi-square test for $\mathrm{H}_{3}$.

Table 10

Chi-Square Test for $\mathrm{H}_{3}$

\begin{tabular}{lcccc}
\hline Chi-Square Test & Value & df & Asymp. Sig. (2-Sided) & Exact Sig. (2-Sided) \\
\hline Pearson Chi-Square & 33.890 & 2 & 0.000 & 0.000 \\
Likelihood Ratio & 40.192 & 2 & 0.000 & 0.000 \\
Fisher's Exact Test & 33.887 & & & 0.000 \\
\hline
\end{tabular}

Source: Authors' research

Table 11

Symmetric Measures of the Chi-Square Test for the $\mathrm{H}_{3}$ Hypothesis

\begin{tabular}{lccc}
\hline Symmetric Measures & Value & Approx. Sig. & Exact Sig. \\
\hline Phi & 0.898 & 0.000 & 0.000 \\
Cramer's V & 0.898 & 0.000 & 0.000 \\
Contingency Coefficient & 0.668 & 0.000 & 0.000 \\
\hline
\end{tabular}

Source: Authors' research

Results of the chi-square test showed statistically significant correlation $(p<0.001)$ between the change in corporate culture and target's performance after the takeover. Besides a statistically significant correlation, a strong practical correlation is also evident due to the fact that all target companies in which corporate culture was changed performed better after the takeover, while only $18.8 \%$ of all target companies in which there was no change in performed better.

Research participants also graded the degree of change in corporate culture and expressed their opinions about the impact of corporate culture on the target's performance after the takeover. Since measuring instrument for corporate culture was adapted to the needs of this research, all statements related to the corporate culture were submitted to reliability analysis using Cronbach's alpha coefficient which was 0.975 and represented a very high value and a strong reliability level. By excluding certain statements from the corporate culture measuring instrument, Cronbach's alpha would not significantly increase. Table 12 shows the descriptive statistics about mean scores of research participants regarding the change of corporate culture and its impact on the target's performance after the takeover. 
Table 12

Mean Scores of the Research Participants Regarding Changes in Corporate Culture and its Impact on the Target's Performance after the Takeover

\begin{tabular}{lcccc}
\hline & Performance after the Takeover & N & Mean & Std. Deviation \\
\hline & Worse & 13 & 1.00 & 0.00000 \\
Change of Corporate Culture (Average) & Better & 30 & 3.42 & 0.96349 \\
& Total & 43 & 2.69 & 1.38077 \\
Perception of Survey Participants about Correlation between & Worse & 13 & 2.00 & 1.069 \\
Change of Target's Corporate Culture and its Performance & Better & 30 & 3.70 & 0.702 \\
& Total & 43 & 3.34 & 1.047 \\
\hline
\end{tabular}

Source: Authors' research

Mean score of research participants whose companies performed worse after the takeover was 1 which implies that there was no change in corporate culture after the transaction. Research participants whose companies performed better graded the change in corporate culture with 3.42 implying that there was a moderate change in corporate culture after the takeover. Correlation between change in corporate culture and target's performance after the takeover was graded with 2 (they think that correlation is week) by research participants whose companies performed worse after the takeover, while research participants coming from target companies that performed better after the transaction graded that correlation with 3.70 (they think correlation is strong). In order to test whether there is a significant difference between mean scores of research participants whose companies performed worse or better after the takeover, variance analysis was used.

Table 13 presents the variance analysis for $\mathrm{H}_{3}$.

Table 13

Variance Analysis for $\mathrm{H}_{3}$

\begin{tabular}{|c|c|c|c|c|c|c|}
\hline ANOVA & & $\begin{array}{c}\text { Sum of } \\
\text { Squares }\end{array}$ & df & Mean Square & $\mathrm{F}$ & Sig. \\
\hline \multirow{3}{*}{ Change of Corporate Culture (Average) } & Between Groups & 53.153 & 1 & 53.153 & \multirow{3}{*}{80.949} & \multirow{3}{*}{0.000} \\
\hline & Within Groups & 26.921 & 41 & 0.657 & & \\
\hline & Total & 80.074 & 42 & & & \\
\hline Perception of Survey Participants about & Between Groups & 18.253 & 1 & 18.253 & \multirow{3}{*}{29.466} & \multirow{3}{*}{0.000} \\
\hline Correlation between Change of Target's & Within Groups & 22.300 & 41 & 0.619 & & \\
\hline Corporate Culture and its Performance & Total & 40.553 & 42 & & & \\
\hline
\end{tabular}

Source: Authors' research

Variance analysis showed significant difference $(\mathrm{p}<0.001)$ between mean scores of survey participants whose companies performed worse or better when observing the degree of culture change as well as correlation between change in corporate culture and target's performance after the takeover. Since chi-square test confirmed a statistically significant correlation $(\mathrm{p}<$ 0.001 ) between the change of target's corporate culture and its performance after the takeover and based on the variance analysis it can be concluded that employees' perception about larger change of corporate culture after the takeover is related to better target's performance after the takeover which confirms $\mathrm{H}_{3}$.

\section{Discussion and Conclusion}

Mergers and acquisitions represent important business activities that may influence corporate world and global economy. The business reality is that most of M\&As do not accomplish 
prearranged synergies and effects, therefore the objective of this paper was to analyze the impact of key organizational variables (strategy, structure, and corporate culture) on the success of acquisition strategy. Based on the sample of 43 target companies, validity of the proposed hypothesis was tested through empirical research.

Empirical research has confirmed a statistically significant correlation between the radical change in the target's strategy and its performance after the takeover. A radical change of business strategy in the acquired company enables new management to allocate and utilize resources in a more efficient way compared to the period prior to the takeover which reflects on target's successful performance. In order to successfully implement business strategy, it is important to adjust company's structure; to this end, importance of changes in organizational structure for target's better performance has also been statistically confirmed. Chi-square test confirmed a statistically significant correlation between changes in organizational structure and target's performance after the takeover and therefore, it is concluded that changes in organizational structure of the target company are related with better target's performance after the takeover. After analyzing the change of the business strategy and organizational structure, empirical research confirmed that there is a statistically significant correlation between larger change in corporate culture and target's performance after the takeover. Regarding the fact that corporate culture represents the way of life and work in the company, change in corporate culture which was present in the target during period of poor performance is extremely important for better performance after the takeover. Therefore, it is necessary to change the corporate culture of the target company to achieve a successful takeover.

For future research, methodological improvements are noticeable. For instance, examination of the takeovers in one particular industry may significantly contribute to the conclusions regarding successful takeovers. However, this suggestion is not applicable in Croatia due to the limited number of transactions that could be analyzed within one industry. Different research methodology could also be used as undoubted methodological improvement. Research based on case study is recognized and accepted methodology used in the social sciences and such method might result in credible and reliable findings and conclusions. Despite the potential improvements that can be expected in future empirical research, the findings of the conducted theoretical and empirical research affirm the relevance of the impact that strategy, organizational structure, and corporate culture have on the takeover success. By accepting suggestions regarding methodological improvements, it is possible to remove the indicated limitations of the conducted research.

Considering the results of the conducted empirical research and results of the previous studies about the impact of strategy, organizational structure, and corporate culture on takeover success, it can be concluded that it is important for the success of the takeover to make changes in target's strategy, organizational structure, and corporate culture. Finally, the outcomes of the current research can lead to the expansion of the number of successful takeovers not only in Republic of Croatia, but also in other counties with active M\&A arena.

\section{References}

Agwin, D. (2007). Mergers and acquisitions. Malden, MA: Blackwell Publishing. 
Allred, B. B., Boal, K. B., \& Holstein, W. K. (2005). Corporations as stepfamilies: A new metaphor for explaining the fate of merged and acquired companies. Academy of Management Executive, 19(3), 23-37.

Altunbaş, Y., \& Marqués, D. (2008). Mergers and acquisitions and banking performance in Europe: The role of strategic similarities. Journal of Economics \& Business, 60(3), 204-222.

Appelbaum, S. H., Gandell, J., Yortis, A., Proper, S., \& Jobin, F. (2000). Anatomy of a merger: Behavior of organizational factors and processes throughout the pre-during-post-stages (part 1). Management Decision, 38(9), 649-661.

Barney, J. B. (1986). Strategic factor markets: Expectations, luck, and business strategy. Management Science, 32(10), 12311241.

Brock, D. M. (2005). Multinational acquisition integration: The role of national culture in creating synergies. International Business Review, 14(3), 269-288.

Bruton, G. D., Oviatt, B. M., \& White M. A. (1994). Performance of acquisition of distressed firms. Academy of Management Journal, 37(4), 972-989.

Buble, M. (2005). Uvod u strateški menadžment. In Buble, M. (Eds.), Strateški menadžment (pp. 1-15). Zagreb: Sinergija.

Burner, F. R. (2001). Does M\&A pay? A survey of evidence for the decision-maker. Journal of Applied Finance, 12(1), 48-68.

Cartwright, S., \& Cooper, C. L. (1993). The psychological impact of merger and acquisition on the individual: A research of building society managers. Human Relations, 46, 327-347.

Chatterjee, S. (1986). Types of synergy and economic value: The impact of acquisitions on merging and rival firms. Strategic Management Journal, 7(2), 119-139.

Chatterjee, S., Lubatkin, M., Schweiger, D. M., \& Weber, Y. (1992). Cultural differences and shareholder value in related mergers: Linking equity and human capital. Strategic Management Journal, 13(5), 319-334.

Cingula, M. (2005). Implementacijastrategije. In Buble, M. (Eds), Strateški menadžment (pp. 157-166). Zagreb: Sinergija.

Cingula, M., Filipović, D., \& Podrug, N. (2010) Mergers and acquisitions in Croatia and Lithuania. Journal of International Scientific Publication: Economy \& Business, 4(2), 349-364.

Collis, D. J., \& Montgomery, C. A. (2005). Corporate strategy: A resource-based approach. New York: McGraw-Hill.

Damodaran, A. (2002). Investment valuation: Tools and technique for determining the value of any asset. New York: John Wiley \& Sons Inc.

DePamphilis, D. M. (2008). Mergers, acquisitions, and other restructuring activities (4 ${ }^{\text {th }}$ ed.). San Diego: Academic Press.

DePamphilis, D. M. (2014). Mergers, acquisitions, and other restructuring activities ( $^{\text {th }}$ ed.). San Diego: Academic Press.

Drucker, P. F. (1989). The practice of management. Portsmouth: Heinemann Professional.

Ernst, H., \& Vitt, J. (2000). The influence of corporate acquisitions on the behavior of key inventors. R\&D Management, $30(2), 105-120$.

Fama, E., Fisher, L., Jensen, M., \& Roll, R. (1969). The adjustment of stock prices to new information. International Economic Review, 10(1), 1-21.

Farmer, R. T. (2005). Corporate culture defines a company and its future. American Journal of Business, 20(2), 7-10.

Filipović, D. (2012). Impact of the company’s size on takeover success. Economic research, 25(2), 435-444.

Filipović, D., Sapunar, I., \& Sapunar, G. (2011). Overview of crucial variables for M\&A success. Annals of DAAAM \& Proceedings of the 22nd International DAAAM Symposium, 22(1), 807-808.

Gamble, J. E., Thompson, A. A., \& Peteraf, M. (2012). Essentials of strategic management: The quest for competitive advantage. New York: McGraw-Hill/Irwin.

Goldsmith, W., \& Clutterbuck, D. (1998). The winning streak mark II. London: Orion Business Books.

Harrison, S. J., Hitt, M. A., Hoskisson, R. E., \& Ireland, R. D. (1991). Synergies and post-acquisition performance: Differences versus similarities in resource allocations. Journal of Management, 17(1), 173-190.

Heller, R. (1997). In search of European excellence. New York: HarperCollins Publishers.

Hill, C. W. L., \& Jones, G. R. (2008). Strategic management: An integrated approach. Boston, MA: Houghton Mifflin Company.

Jemison, D. B., \& Sitkin, S. B. (1986). Corporate acquisitions: A process perspective. Academy of Management Review, 11(1), $145-163$.

Kandžija, V., Filipović, D., \& Kandžija, T. (2014). Impact of industry structure on success of mergers and acquisitions. Tehničkivjesnik - Technical Gazette, 21(1), 17-25. 
Karim, S. (2006). Modularity in organizational structure: The reconfiguration of internally developed and acquired business units. Strategic Management Journal, 27(9), 799-823.

Kim, J., \& Finkelstein, S. (2009). Effects of strategic and market complementary on acquisition performance: Evidence from the U.S. commercial banking industry, 1989-2001. Strategic Management Journal, 30(6), 617-646.

Krishanan, H. A., Hitt, M. A., \& Park, D. (2007). Acquisition premiums, subsequent workforce reductions and post-acquisition performance. Journal of Management Studies, 44(5), 709-732.

Larsson, R., \& Finkelstein, S. (1999). Integrating strategic, organizational, and human resource perspectives on mergers and acquisitions: A case survey of synergy realization. Organizational Science, 10(1), 1-26.

Larsson, R., \& Lubatkin, M. H. (2001). Achieving acculturation in mergers and acquisitions: An international case survey. Human Relations, 54(12), 1573-1607.

Lodorfos, G., \& Boateng, A. (2006). The role of culture in the merger and acquisition process: Evidence from European chemical industry. Management Decision, 44(10), 1405-1406.

Marks, M. L., \& Mirvis, P. H. (2000). Managing mergers, acquisitions and alliances: Creating an effective transition structure. Organizational Dynamics, 28(3), 35-46.

Marynova, M., \& Renneboog, L. (2008). A century of corporate takeovers: What have we learned and where do we stand? Journal of Banking \& Finance, 32(10), 2148-2177.

Mullins, L. J. (2010). Management and organizational behavior. Harlow: Pearson Education Limited.

Nahavandi, A., \& Malekzadeh, A. (1988). Acculturation in mergers and acquisition. Academy of Management Review, 13(1), 79-90.

Peters, T., \& Waterman, R. H. (2008). U potrazizaizvrsnošću. Zagreb: Profil International.

Porter, M. E. (1980). Competitive strategy: Techniques for analyzing industries and competitors. New York: The Free Press.

Puranam, P, Singh, H., \& Chaudhuri, S. (2009). Integrating acquired capabilities: When structural integration is (Un) necessary. Organization Science, 20(2), 313-328.

Quah, P., \& Young, S. (2005). Post-acquisition Management: A Phases Approach for Cross-border M\&As. European Management Journal, 23(1), 65-75.

Ramaswamy, K. (1997). The performance impact of strategic similarity in horizontal mergers: Evidence from US banking industry. Academy of Management Journal, 40(3), 697-715.

Ravenscraft, D. J., \& Scherer, F. M. (1989). The profitability of mergers. International Journal of Industrial Organization, 7(1), 101-116.

Safford, G. (1988). Culture traits, strength, and organizational performance: Moving beyond strong culture. Academy of Management Review, 13(4), 546-558.

Schoenberg, R. (2006). Measuring the performance of corporate acquisitions: An empirical comparison of alternative metrics. British Journal of Management, 17(4), 361-370.

Sikavica, P., \& Novak, M. (1999). Poslovna organizacija. Zagreb: Informator.

Stahl, G. K., \& Voigt, A. (2008). Do cultural differences matter in merger and acquisition? A tentative model and examination. Organization Science, 19(1), 160-176.

Sudarsanam, S. (2010). Creating value from mergers and acquisitions. London: Prentice Hall International Limited.

Tipurić, D. (1999). Konkurentska sposobnost poduzeća. Zagreb: Sinergija.

Tipurić, D. (2005). Alternativne strategije. In Buble, M. (Eds), Strateški menadžment (109-153), Zagreb: Sinergija.

Tirole, J. (2006). The theory of corporate finance. Princeton NJ: Princeton University Press. 